Janowitz, H. D., and Grossman, M. I. (1950). Fournal of Investigative Dermatology, 14, 453.

Johnson, R. H., Lee, G. de J., Oppenheimer, D. R., and Spalding, J. M. K. (1966). Quarterly fournal of Medicine, 35, 276.

Johnson, R. H., Smith, A. C., Spalding, J. M. K., and Wollner, L. (1965). Lancet, 1, 731 .

Lewy, F. W. (1923). Die Lehre vom Tonus und der Bewegung. Berlin, Springer. Luft, R., and von Euler, U. S. (1953). Fournal of Clinical Investigation, 32.

McDowell, F. H. (1970). In L-Dopa and Parkinsonism, ed. A. Barbeau and F. H. McDowell, p. 263. Philadelphia, Davis.

Martin, J. B., Travis, R. H., and Noort, S. van den (1968). Archives of Neurology, 19, 163

Murnaghan, G. F. (1961). British Fournal of Urology, 33, 403.

Onesti, G., Schwarz, A. B., Kim, K. E., Paz-Martinez, V., and Schwarz, C. (1971). Circulation Research, 28, Suppl. 2, p. 53.

Parkinson, J. (1817). An Essay on the Shaking Palsy. London. Reprinted in Fames Parkinson (1755-1824), ed. M. Critchley, London, Macmillan.

Pickering, G. W. (1955). High Blooa Pressure. London, Churchill.

Porter, R. W. Bors, E., and Hyman, W. (1969). In Third Symposium on

Parkinson's Disease, ed. F. J. Gillingham and I. M. C. Donaldson, p. 124. Edinburgh, Livingstone.
Reid, J. L., Calne, D. B., George, C. F., and Vakil, S. D. (1971). Clinical Science, 40, 6P.

Schmitt, H., Schmitt, H., Boissier, J. R., Giudicelli, J. P., and Fichelle, J. (1968). European fournal of Pharmacology, 2, 340.

Schwarz, G. A. (1967). Archives of Neurology, 16, 123. harpey-Schafer, E. P. (1965). In Handbook of Physiology, vol. 3, Section 2, Circulation, ed. W. F. Hamilton and P. Dow. p. 1875

Sharpey-Schafer, E. P., and Taylor, P. J. (1960). Lancet, 1, 559.

Shy, G. M., and Drager, G. A. (1960). Archives of Neurology, 2, 511

Spiegel, E. A., Wycis, H. T., Schor, S., Schwartz, H. A., and Fabioni, F. R. (1969). In Third Symposium on Parkinson's Disease, ed. F. J. Gillingham and I. M. C. Donaldson, p. 200. Edinburgh, Livingstone.

Stead, E. A., jun., and Ebert, R. V. (1941). Archives of Internal Medicine, $67,546$.

Thomas, J. E., and Schirger, A. (1970). Archives of Neurology, 22, 289.

Vanderhaeghen, J. J., Perier, O., and Sternon, J. E. (1970). Archives of Neurology, 22, 207.

Verel, D. (1951). British Heart fournal, 13, 61.

Yahr, M. D., Duvoisin, R. C., Hoehn, M. M., Schear, M. J., and Barrett, R. E. (1968). Transactions of the American Neurological Association, 93, 56.

\title{
Endogenous Creatinine Clearance as a Clinical Measure of Glomerular Filtration Rate*
}

\author{
WILLIAM M. BENNETT, GEORGE A. PORTER
}

British Medical fournal, 1971, 4, 84-86

\section{Summary}

Endogenous creatinine clearance was assessed by inulin in 91 simultaneous studies in 41 patients and proved an accurate measurement of glomerular filtration rate. For filtration rates $<20 \mathrm{ml} / \mathrm{min}$ the creatinine clearance may slightly overestimate the glomerular filtration rate. Successive determinations of filtration rate by either method may vary by $20 \%$ even though the methods agree with each other. Glomerular filtration rate itself is variable, and in its clinical usage this should be recognized.

\section{Introduction}

A report by Kim et al. (1969) has questioned again the validity of the endogenous creatinine clearance for the clinical estimation of the glomerular filtration rate. Based on 308 simultaneous determinations of inulin and creatinine clearances these authors reported that the creatinine clearance overestimated the filtration rate as measured by inulin in both normal patients and those with kidney disease. Not only did the ratio of creatinine clearance to inulin clearance increase as filtration rate declined but they also found a ratio greater than one in the normal range. If these findings are valid, then the usefulness of creatinine clearance as a screening test of renal function would be limited.

Our experience is at variance with these observations. In our experience inulin clearance and creatinine clearance showed close correlation. However, the filtration rate itself was variable over both the short term and the long term by either measuring technique. We feel that this point needs emphasis, since thera-

* Supported by PHS-CV Program Project HE 06336-10 CRC 5 MOI RR 334-05.

Renology Section, University of Oregon Medical School, Portland, Oregon, U.S.A.

WILLIAM M. BENNETT, M.D., Assistant Professor of Medicine GEORGE A. PORTER, M.D., Associate Professor of Medicine peutic decisions must take into account spontaneous variations in filtration rate or run the risk of being erroneous.

\section{Methods}

Ninety-one simultaneous inulin and creatinine clearances were performed in 41 patients. Six patients were normal volunteers, 19 were undergoing cardiac catheterization under local anaesthesia but had no known renal disease, and 16 had a variety of renal diseases. There were 16 men and 25 women ranging in age from 18 to 69 .

Priming doses of $10 \%$ inulin of $50 \mathrm{mg} / \mathrm{kg}$ were given followed by a constant infusion of $2 \mathrm{ml} / \mathrm{min}$ with an infusion pump (Porter et al., 1966). Forty-five minutes were allowed for equilibration and no clearance was used unless plasma inulin was $25-35 \mathrm{mg} / 100$ and urine flow was at least $2 \mathrm{ml} / \mathrm{min}$. All studies were done in supine patients without water loading. Complete urine collections were insured by indwelling bladder catheterization and aspiration of the bladder followed by two air rinses after each 15-minute clearance period. Inulin was determined tiy the method of Roe et al. (1949) and endogenous creatinine by a total chromogen method as described by Haugen (1953). After equilibration three 15-minute clearances were averaged. Duplicate samples of blood and urine were processed for inulin and creatinine. Inulin duplicates varied by $1 \cdot 7 \pm 3 \%$ for plasma and $2 \cdot 2 \pm 2 \%$ for urine, while creatinine varied by $0.4 \pm 1.3 \%$ for serum and $0.2 \pm 0.3 \%$ for urine.

Thirty-nine patients had successive clearance studies repeated one hour after the initial study while still in a steady state of plasma inulin and urine flow. Clearance rates were computed by the standard formula (Homer Smith, 1956) but correction to a standard body surface area was performed only in the 19 cardiac catheterization patients.

\section{Results}

Fig. 1 is a correlation of endogenous creatinine clearance $\left(\mathrm{C}_{\mathrm{cr}}\right)$ to inulin clearance $\left(\mathrm{C}_{\mathrm{in}}\right)$ for the entire series, while Fig. 2 depicts the U/P ratios. The relationship is essentially linear. The correlation is striking, with a mean ratio of $\mathrm{C}_{\mathrm{cr}} / \mathrm{C}_{\text {in }}$ of $0.95 \pm 0.03$. When the patient results were divided into those 


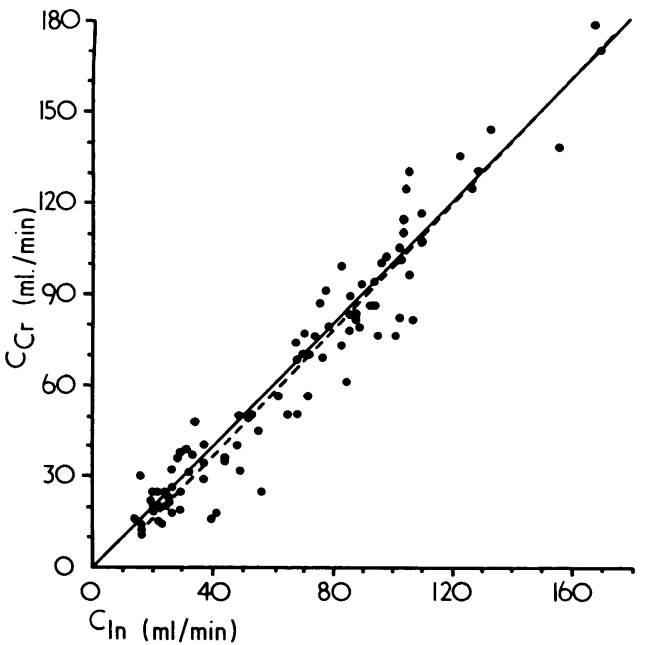

FIG. 1-Correlation plot of 91 simultaneous rates of inulin and creatinine performed in 41 patients. The identity line is the solid line and the regression line of the plotted points $(y=1.028 x-4 \cdot 4)$ is the interrupted line. Correlation coefficient is 0.98 .

TABLE I-Ratio of Creatinine Clearance to Inulin Clearance for 91 Simultaneous Determinations. Difference between those Done with $C_{\mathrm{in}}>50 \mathrm{ml} / \mathrm{min}$ and those $<50 \mathrm{ml} / \mathrm{min}$ is Not Statistically Significant

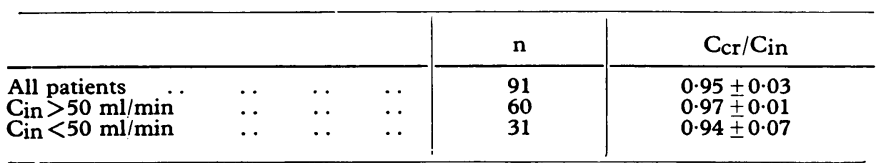

TABLE II-Inulin and Creatinine Clearance in 39 Patients with Successive Studies

\begin{tabular}{|c|c|c|c|c|c|c|c|}
\hline Case No. & Category & Age & Sex & $\mathrm{C}_{\mathrm{in}_{1}}$ & Cin: & $\mathrm{C}_{\mathrm{cr} 1}$ & $\mathrm{C}_{\mathrm{cr} 2}$ \\
\hline $\begin{array}{r}1 \\
2 \\
3 \\
4 \\
5 \\
6 \\
7 \\
8 \\
9 \\
10 \\
11 \\
12 \\
13 \\
14 \\
15 \\
16 \\
17 \\
18 \\
19 \\
20 \\
21 \\
22 \\
23 \\
24 \\
25 \\
26 \\
27 \\
28 \\
29 \\
30 \\
31 \\
32 \\
33 \\
34 \\
35 \\
36 \\
37 \\
38 \\
39\end{array}$ & $\begin{array}{l}\text { Normal } \\
\text { Normal } \\
\text { Normal } \\
\text { Normal } \\
\text { Normal } \\
\text { Cardiac cath. } \\
\text { Cardiac cath. } \\
\text { Cardiac cath. } \\
\text { Cardiac cath. } \\
\text { Cardiac cath. } \\
\text { Cardiac cath. } \\
\text { Cardiac cath. } \\
\text { Cardiac cath. } \\
\text { Cardiac cath. } \\
\text { Cardiac cath. } \\
\text { Cardiac cath. } \\
\text { Cardiac cath. } \\
\text { Cardiac cath. } \\
\text { Cardiac cath. } \\
\text { Cardiac cath. } \\
\text { Cardiac cath. } \\
\text { Cardiac cath. } \\
\text { Cardiac cath. } \\
\text { Cardiac cath. } \\
\text { Renal } \\
\text { Renal } \\
\text { Renal } \\
\text { Renal } \\
\text { Renal } \\
\text { Renal } \\
\text { Renal } \\
\text { Renal } \\
\text { Renal } \\
\text { Renal } \\
\text { Renal } \\
\text { Renal } \\
\text { Renal } \\
\text { Renal } \\
\text { Renal }\end{array}$ & $\begin{array}{l}27 \\
30 \\
28 \\
36 \\
18 \\
31 \\
26 \\
19 \\
28 \\
28 \\
47 \\
32 \\
39 \\
48 \\
28 \\
25 \\
51 \\
69 \\
49 \\
24 \\
31 \\
40 \\
22 \\
33 \\
33 \\
24 \\
46 \\
43 \\
39 \\
50 \\
41 \\
34 \\
36 \\
47 \\
54 \\
61 \\
29 \\
28 \\
37\end{array}$ & 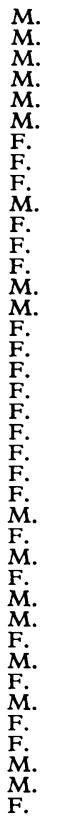 & $\begin{array}{r}105 \\
103 \\
211 \\
168 \\
110 \\
101 \\
49 \\
72 \\
130 \\
62 \\
79 \\
68 \\
69 \\
104 \\
78 \\
93 \\
99 \\
94 \\
70 \\
93 \\
107 \\
88 \\
98 \\
83 \\
26 \\
83 \\
41 \\
19 \\
20 \\
25 \\
37 \\
29 \\
25 \\
26 \\
34 \\
23 \\
85 \\
24 \\
37\end{array}$ & $\begin{array}{r}133 \\
103 \\
196 \\
127 \\
156 \\
77 \\
52 \\
66 \\
123 \\
86 \\
71 \\
95 \\
81 \\
105 \\
68 \\
86 \\
68 \\
94 \\
74 \\
91 \\
103 \\
72 \\
106 \\
76 \\
16 \\
95 \\
55 \\
22 \\
16 \\
25 \\
48 \\
17 \\
22 \\
28 \\
32 \\
23 \\
65 \\
33 \\
34\end{array}$ & $\begin{array}{r}124 \\
101 \\
214 \\
186 \\
107 \\
76 \\
50 \\
70 \\
129 \\
56 \\
80 \\
50 \\
68 \\
110 \\
91 \\
86 \\
102 \\
86 \\
70 \\
56 \\
81 \\
81 \\
100 \\
99 \\
18 \\
73 \\
18 \\
22 \\
25 \\
23 \\
29 \\
39 \\
20 \\
32 \\
48 \\
25 \\
61 \\
26 \\
44\end{array}$ & $\begin{array}{r}144 \\
105 \\
196 \\
125 \\
138 \\
69 \\
49 \\
72 \\
135 \\
78 \\
77 \\
76 \\
80 \\
114 \\
74 \\
83 \\
73 \\
89 \\
76 \\
74 \\
82 \\
71 \\
96 \\
87 \\
11 \\
86 \\
26 \\
20 \\
11 \\
23 \\
40 \\
30 \\
15 \\
36 \\
39 \\
15 \\
50 \\
37 \\
36\end{array}$ \\
\hline
\end{tabular}

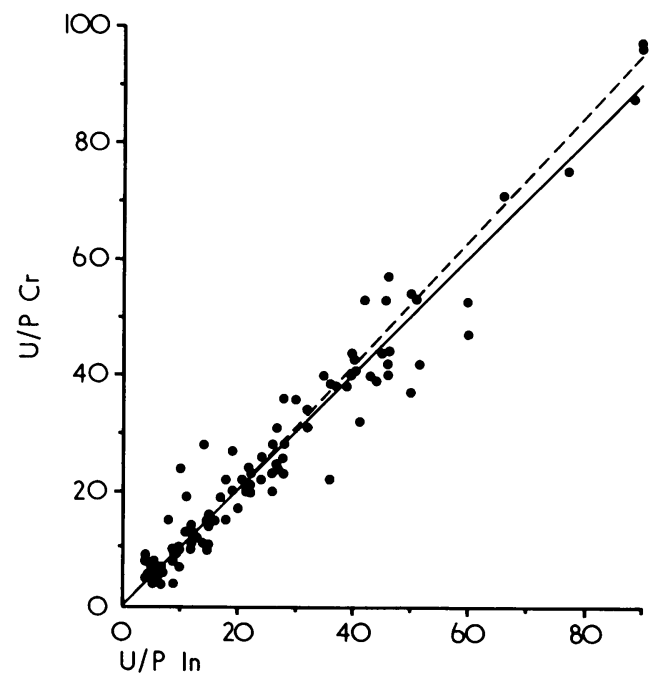

FIG. 2-Correlation plot of 91 simultaneous $U / P$ ratios of inulin and creatinine the regression line coefficient is 0.95 .

with $\mathrm{C}_{\text {in }}$ greater than $50 \mathrm{ml} / \mathrm{min}$ and those with less than $50 \mathrm{ml} / \mathrm{min}$ the difference in the mean $\mathrm{C}_{\mathrm{cr}} / \mathrm{C}_{\mathrm{in}}$ ratios of the two groups were not statistically significant. These data are shown on Table I. These results would seem to support the contention that $\mathrm{C}_{\mathrm{cr}}$ is an accurate reflection of filtration rate as measured by inulin at any level of renal function.

Table II lists the data obtained from the 39 patients who had successive clearance studies after an hour while in a steady state of plasma inulin and urine flow. The differences in the first and second clearances, expressed in absolute terms and as a percentage of the mean clearance, are shown in Table III. For the 26 patients with inulin clearances greater than 50 $\mathrm{ml} / \mathrm{min}$ the absolute changes were larger but the percentage changes were similar to those of the group as a whole. For the 13 patients with inulin clearances less than $50 \mathrm{ml} / \mathrm{min}$ the percentage changes in successive studies were over $20 \%$ of the mean clearances.

Clearance data are available for the 19 cardiac catheterization patients expressed as $\mathrm{ml} / \mathrm{min} / 1 \cdot 73 \mathrm{M}^{2}$. For inulin the value is $88 \pm 16 \mathrm{ml} / \mathrm{min}$ compared with $84 \pm 18 \mathrm{ml} / \mathrm{min}$ when the clearance is calculated without factoring by surface area. Simultaneous creatinine clearance is $85 \pm 17$ expressed as $\mathrm{ml} / \mathrm{min} / 1 \cdot 73 \mathrm{M}^{2}$ versus $82 \pm 20 \mathrm{ml} / \mathrm{min}$. These differences are not statistically significant.

\section{Discussion}

The endogenous clearance of creatinine has attained widespread clinical usage as a convenient, accurate measurement of glomerular filtration rate. Data published by Kim et al. (1969) have suggested that the endogenous creatinine clearance overestimates the true filtration rate as determined by inulin clearance throughout the entire range of renal function. This conclusion is at variance with our data shown in Fig. 1 and Table $I$ in which a striking correlation between inulin and creatinine clearance is evident. The ratio $\mathrm{C}_{\mathrm{cr}} / \mathrm{C}_{\text {in }}$ which we

TABLE III-Variability of Glomerular Filtration Rate. Data showing Absolute Difference and Percentage Difference of Clearance Studies in 39 Patients Done after One Hour while in a Steady State

\begin{tabular}{|c|c|c|c|c|c|c|c|c|c|c|}
\hline \multirow{2}{*}{\multicolumn{4}{|c|}{ Description }} & \multirow{2}{*}{$\mathrm{n}$} & \multicolumn{2}{|c|}{$\overline{\mathrm{x}}$ G.F.R. (ml/min) } & \multicolumn{2}{|c|}{ Absolute Diff. $C_{1}-C_{2}(\mathrm{ml} / \mathrm{min})$} & \multicolumn{2}{|c|}{$\frac{\text { Absolute } C_{1}-C_{2}}{X C} \times 100(\%)$} \\
\hline & & & & & $\mathrm{C}_{\text {in }}$ & $\mathrm{C}_{\mathrm{cr}}$ & $\mathrm{C}_{\text {in }}$ & $\mathrm{C}_{\mathrm{cr}}$ & $\mathrm{C}_{\text {in }}$ & $\mathrm{C}_{\mathrm{cr}}$ \\
\hline $\begin{array}{l}\text { All patients } \\
\mathrm{C}_{\text {in }}>50 \mathrm{ml} / \mathrm{min} \\
\mathrm{C}_{\text {in }}>50 \mathrm{ml} / \mathrm{min}\end{array}$ & $\begin{array}{l}\ldots \\
\cdots \\
\cdots\end{array}$ & $\begin{array}{l}\cdots \\
\cdots\end{array}$ & $\begin{array}{l}\cdots \\
\cdots\end{array}$ & $\begin{array}{l}39 \\
26 \\
13\end{array}$ & $\begin{array}{l}73 \pm 12 \\
95 \pm 15 \\
29 \pm 8\end{array}$ & $\begin{array}{l}71 \pm 13 \\
93 \pm 12 \\
27 \pm 9\end{array}$ & $\begin{array}{r}12 \pm 2 \\
15 \pm 2 \\
6 \pm 1\end{array}$ & $\begin{array}{r}11+2 \\
13 \pm 3 \\
7 \pm 1\end{array}$ & $\begin{array}{l}15 \\
16 \\
21\end{array}$ & $\begin{array}{l}16 \\
14 \\
27\end{array}$ \\
\hline
\end{tabular}


obtained is similar to those of other investigators as noted in the review of Doolan et al. (1962).

In analysing the data of $\mathrm{Kim}$ et al. two possibilities are suggested for the discrepancy. Firstly the normal values they report for inulin clearance-that is, $95 \pm 17 \mathrm{ml} / \mathrm{min}$ for men and $94 \pm 16$ for women-are considerably below the $124 \pm 26$ for men and $109 \pm 13$ for women published by Homer Smith (1956). Secondly, it is possible that their patients were not in a steady state after preclearance water loading. It has been shown by Porter et al. (1966) that sudden augmentation of urine flow may "wash out" a reservoir of creatinine, presumably from renal tubular cells. The increased rate of tubular transit tends to make the $U / P$ ratio for creatinine less at any one time, creating a more favourable gradient for creatinine excretion. The net effect during the period of "wash out" would be for creatinine clearance to overestimate simultaneously measured inulin filtration rate.

It has been well established that creatinine can be secreted by the renal tubules particularly if the glomerular filtration rate is decreased-that is, $\mathrm{C}_{\mathrm{cr}}>\mathrm{C}_{\mathrm{in}}$ (Brod and Sirota, 1948; Miller et al., 1952). This is usually true only if the serum creatinine is measured as true creatinine and not as total chromogen. When the latter is used (most clinical laboratories and autoanalyzer techniques) the addition of non-creatinine chromogens increase the measured serum creatinine and cancels out the urinary creatinine contributed by tubular secretion. The absolute amount of non-creatinine chromogen stays relatively constant as the filtration rate falls and true creatinine rises with renal disease. Thus the creatinine clearance tends to increase in relation to inulin when tubular secretion is maximal (low filtration rate) and non-creatinine chromogen is a small fraction of serum creatinine. Skov (1970) showed that with severe renal disease $C_{c r}$ may overestimate $C_{i n}$. Twenty-two of his patients had $C_{i n}$ less than $5 \mathrm{ml} / \mathrm{min}$ while our series had only four patients below $20 \mathrm{ml} / \mathrm{min}$. The low filtration rates of his series no doubt account for the higher $\mathrm{C}_{\mathrm{cr}} / \mathrm{C}_{\text {in }}$ observed.

What was variable in our study were successive inulin or creatinine clearances while in a steady state, and this was true of the normals, the post catheter patients, and those with renal disease. Table II and III summarize these data both in absolute $\mathrm{ml} / \mathrm{min}$ and in perentage. The change in successive creatinine clearance reached as high as $27 \%$ in the
13 patients with inulin clearances $<50 \mathrm{ml} / \mathrm{min}$. It is noteworthy that this is the range of filtration rate found in many patients with various renal diseases and after renal transplantation. If the spontaneous variability of filtration rate is not recognized erroneous conclusions as regards progression of disease or results of therapy may be drawn. Though with a 24-hour clearance of creatinine the variability of successive clearances might be minimized, the urinary excretion of creatinine is also inconstant as Edwards et al. (1969) emphasized. Further, it is obvious that variation in the production or excretion of creatinine cannot explain the inconstancy of inulin clearances.

In 30 of the 39 patients successive $C_{i n}$ and $C_{c r}$ changed in the same direction, increasing 16 times and decreasing 14 times. In the nine instances where $\mathrm{C}_{\mathrm{in}}$ and $\mathrm{C}_{\mathrm{cr}}$ varied in opposite directions the deviations were extremely smallthat is, the values were virtually the same. Thus the change in successive clearances seems to be random.

Brod and Sirota (1948) found that proteinuria enhanced creatinine excretion and thus increased $\mathrm{C}_{c r}$ in relation to $\mathrm{C}_{i n}$. In our series proteinuria was just as common when $C_{i n}$ was less than $\mathrm{C}_{\mathrm{cr}}$ as the converse. Studies by Hilton et al. (1969) support this conclusion.

We wish to express our appreciation for the technical help of Jean Kimsey and the secretarial help of Mrs. Ruth Auch.

\section{References}

Kim, K. E., Onesti, G., Ramirez, O., Brest, A. N., and Swartz, G. (1969). British Medical fournal, 4, 11

Roe, J. H., Epstein, J. H., and Goldstein, N. P. (1949). Fournal of Biological Chemistry, 178, 839 .

Haugen, H. N. (1953). Scandinavian Fournal of Clinical and Laboratory Investigation, 5,48 .

Smith, H. W. (1956). Principles of Renal Physiology, New York, Oxford University Press.

Doolan, P. D., Alpen, E. L., and Theil, G. B. (1962). American fournal of Medicine, 32, 65 .

Porter, G. A., et al. (1966). Circulation, 34, 1005.

Brod, J., and Sirota, J. H. (1948). Fournal of Clinical Investigation, 27, 645 Miller, B. F., Leaf, A., Mamby, A. R., and Miller, Z. (1952). Fournal of Clinical Investigation, 31, 309.

Edwards, O. M., Bayliss, R. I. S., and Miller, S. (1969). Lancet, 2, 1165.

Skov, P. E. (1970). Acta Medica Scandinavica, 187, 419.

Hilton, P. J., Lavender, S., Roth, Z., and Jones, N. F. (1969). Lancet, 2, 1215.

\section{Oxygen Therapy for Spontaneous Pneumothorax}

\section{T. C. NORTHFIELD}

\section{British Medical fournal, 1971, 4, 86-88}

\section{Summary}

The rate of absorption of gas from a pneumothorax was studied in 12 patients breathing air and in 10 patients breathing air and a high concentration of oxygen alternately. The mean rate of absorption while breathing air was the same in both groups of patients. In the second group the rate consistently increased during periods of oxygen therapy and decreased again on breathing air. The mean rate of absorption increased fourfold during periods of oxygen therapy. This increase was most pronounced in patients with a large pneumothorax.

Guy's Hospital, London S.E.1

T. C. NORTHFIELD, M.D., M.R.C.P., Senior Medical Registrar

\section{Introduction}

Comroe et al. (1962) pointed out that capillary and venous blood never have gas tensions that add up to total atmospheric pressure. During inhalation of air the total gas pressure in blood from the distal end of a capillary is about $706 \mathrm{~mm}$ $\mathrm{Hg}$, whereas during inhalation of $100 \%$ oxygen it is about $146 \mathrm{~mm} \mathrm{Hg}$. This difference is mainly due to a reduction in partial pressure of nitrogen from $573 \mathrm{~mm} \mathrm{Hg}$ to zero. Though this is accompanied by an increase in the partial pressure of oxygen in arterial blood from 100 to $640 \mathrm{~mm} \mathrm{Hg}$, oxygen utilization in the tissues ensures that the partial pressure of oxygen in end-capillary blood rises only slightly from $40 \mathrm{~mm} \mathrm{Hg}$ to about $53 \mathrm{~mm} \mathrm{Hg}$ (Comroe et al., 1962).

These figures suggest the hypothesis that inhalation of a high concentration of oxygen might increase the rate of absorption of gas from the pleural cavity. A reduction in the total pressure of gases in a pleural capillary would 